\title{
Interest Limitation Rules in the Post-BEPS Era
}

\author{
Tell, Michael
}

Document Version

Accepted author manuscript

Published in:

Intertax

\section{Publication date:}

2017

\section{License}

Unspecified

Citation for published version (APA):

Tell, M. (2017). Interest Limitation Rules in the Post-BEPS Era. Intertax, 45(11), 750-763.

Link to publication in CBS Research Portal

\section{General rights}

Copyright and moral rights for the publications made accessible in the public portal are retained by the authors and/or other copyright owners and it is a condition of accessing publications that users recognise and abide by the legal requirements associated with these rights.

Take down policy

If you believe that this document breaches copyright please contact us (research.lib@cbs.dk) providing details, and we will remove access to the work immediately and investigate your claim. 


\section{Interest Limitation Rules in the Post-BEPS Era Michael Tell}

Journal article (Accepted manuscript)

CITE: Tell, M. (2017). Interest Limitation Rules in the Post-BEPS Era. Intertax, 45(11), 750-763.

Uploaded to Research@CBS: December २०18 


\title{
Interest Limitation Rules in the Post-BEPS Era
}

\author{
By Michael Tell, Associate Professor at Copenhagen Business School, Visiting Scholar at the University of \\ British Columbia and Senior Associate at CORIT Advisory
}

\begin{abstract}
The use of debt is, according to the OECD, one of the simplest profit-shifting techniques available in international tax planning, due to the mobility of money. A debt tax planning strategy can be applied without any people or machinery being moved or re-allocated; it can be done by advisors or in-house specialist sitting at their desks. These (lawful) tax planning strategies undermine the fairness and integrity of tax systems, because multinational entities can use BEPS strategies to gain a competitive advantage over domestic entities, as well as undermining voluntary compliance by all taxpayers, according to the OECD. The focus in the OECD BEPS project and the Anti-Tax Avoidance Directive is to counteract these tax planning strategies to ensure taxation where the value is created (economic activity).

This article focuses on one anti-tax avoidance measure: interest limitation rules as addressed in BEPS action 4 and in ATAD art. 4. The aim of the article is to address the need for interest limitation rules, analyze the recommend approached in BEPS action 4, analyze the minimum interest limitation rule in the EU according to art. 4 in ATAD, and the implications of OECD action 4 and ATAD article 4. Lastly, the article will discuss alternatives to these interest limitation rules as a way to address base erosion and profit shifting.
\end{abstract}

\section{Introduction}

Base Erosion and Profit Shifting has been the hottest buzz-word in international taxation ever since the G20 and the OECD inserted it on the international agenda by launching the infamous BEPS-project in February 2013. ${ }^{1}$ However, the buzz started even earlier at country level post the financial crisis when especially hightax countries looked more into so-called aggressive tax planning and anti-tax avoidance measures, possibly due to emerging deficit and "fairness" issues. ${ }^{2}$

We are now entering a post-BEPS era with final reports and recommendations ready for implementation. Some will be implemented through the multilateral instrument ${ }^{3}$, some through bilateral agreements, some solely by national initiatives, and in the EU some through the Anti-Tax Avoidance Directive ("ATAD") ${ }^{4}$.

This article focuses on one anti-tax avoidance measure: interest limitation rules as addressed in BEPS action $4^{5}$ and in ATAD art. 4. The aim of the article is to address the need for interest limitation rules, analyze the recommend approached in BEPS action 4, analyze the minimum interest limitation rule in the EU according

\footnotetext{
${ }^{1}$ See www.oecd.org/tax/beps/

${ }^{2}$ See also Martins, Corporate Financing, Interest Deduction and Tax Controversies, Intertax 2013, pp. 462-469.

${ }^{3}$ See OCED BEPS action 15 and the "Multilateral Convention to Implement Tax Treaty Related Measures to Prevent Base Erosion and Profit Shifting". An official signing ceremony was held June 72017 in Paris.

${ }^{4}$ See Council Directive 2016/1164 and Proposal for Amending Council Directive 2016/1164 (COM(2016) 687 final).

5 OECD BEPS action 4, Limiting Base Erosion Involving Interest Deductions and Other Financial Payments, dated 22 December 2016.
} 
to art. 4 in ATAD, and the implications of OECD action 4 and ATAD article 4. Lastly, the article will discuss alternatives to these interest limitation rules as a way to address base erosion and profit shifting.

\section{The Need for Interest Limitation Rules?}

In the OECD project, base erosion and profit shifting (BEPS) refers to tax planning strategies that exploit gaps and mismatches in tax rules to artificially shift profits to low or no-tax locations, where there is little or no economic activity. The focus in the OECD BEPS project is to counteract these tax planning strategies to ensure taxation where the value is created (economic activity). These (lawful) tax planning strategies undermine the fairness and integrity of tax systems, because multinational entities can use BEPS strategies to gain a competitive advantage over domestic entities, as well as undermining voluntary compliance by all taxpayers, according to the OECD. Such tax planning strategies includes debt tax planning strategies, where interest and other deductible financial expenses are used to shift profits away from high(er) tax countries to low(er) tax countries.

The use of debt is, according to the OECD, perhaps one of the simplest profit-shifting techniques available in international tax planning, due to the mobility of money. ${ }^{6} \mathrm{~A}$ debt tax planning strategy can be applied without any people or machinery being moved or re-allocated; it can be done by advisors or in-house specialist sitting at their desks. It is, therefore, no wonder that 4 out of the 7 aggressive tax planning models identified in the European Commission's report Study of Aggressive Tax Planning and Indicators ${ }^{7}$ involve a debt tax planning strategy. ${ }^{8}$ In many (high tax) countries, specific provisions on thin capitalization have been enacted to counteract such debt tax planning strategies, but these seems to be inadequate since these debt tax planning strategies are still widely used to create value for companies. ${ }^{9}$

The value creation in debt tax planning strategies is quite simple and based on two rather simple elements: firstly, the ability to shift tax base away (profit shifting by obtaining a deduction), and secondly, the ability to shift the tax base to another jurisdiction with a lower taxation or no taxation, or just to obtain the debt where the value of the deduction is the highest. ${ }^{10}$ The deduction of interest is thus what creates the possibility of profit shifting, while the different taxation (due to different tax rates or different tax base definition) is the incentive to use a debt tax planning strategy. These so-called tax avoidance maneuvers, debt tax planning strategies, step transactions etc. can erode the tax systems and the fairness of the tax system, and thereby erode the general trust in the tax system. ${ }^{11}$

Some examples of debt tax planning mentioned by the OECD include:

$$
\text { groups placing high levels of third-party debt in high tax countries, }
$$

\footnotetext{
${ }^{6}$ See OECD BEPS action 4, p. 21.

${ }^{7}$ See Study on Structures of Aggressive Tax Planning and Indicators, final report, Taxation Papers, Working Paper n. 612015 , ISSN 1725-7565.

8 The remaining 3 models are centered around intangible assets, which are also highly mobile.

${ }_{9}^{9}$ See OECD BEPS action 4, introduction, pp. 23- 26 and also Millan and Roch, Limit Base Erosion via Interest Deduction and Others, Intertax 2015, pp. 58-71.

${ }^{10}$ See also Knöller, The Efficacy of Thin Capitalization Rules and Their Barriers: An Analysis from the UK and German Perspective, Intertax 2011, pp. 317-336.

11 See also Ostas and Hilling, America Business Law Journal, 2016, pp. 745-785. They argued that social responsibility and ethics will only go so far in the face of temptation, and legal reforms seem necessary to change economic incentives posed by global tax havens. See further See Millan and Roch, Limit Base Erosion via Interest Deduction and Others, Intertax 2015, pp. 58.71 which indicates that sound public welfare and fairness is the ultimate goals underlying OECD BEPS action 4 and interest limitation rules enacted in many countries.
} 
(ii) groups using intra-group loans to generate interest deductions in excess of the group's actual third-party interest expense, and

(iii) groups using third-party or intra-group financing to fund the generation of tax-exempt income. ${ }^{12}$

The examples mentioned in the European Commission's report Study of Aggressive Tax Planning and Indicators include:

(i) off-shore group financing company (model 1),

(ii) hybrid loan structure (model 2),

(iii) hybrid entity structure (model 3), and

(iv) interest free loan adjusted with deemed interest according to local transfer pricing regulation (model 4).

The essential elements of model 1,2, and 4 in the EC report are the deduction of interest and a low or nontaxation of the interest (non-inclusion), while the essential of model 3 is a double deduction of the interest. ${ }^{13}$ Model 1 is illustrated in the report as follows, where a debt planning strategy is used to shift taxable profit from MS C to State D using interest payments passing through MS B: ${ }^{14}$

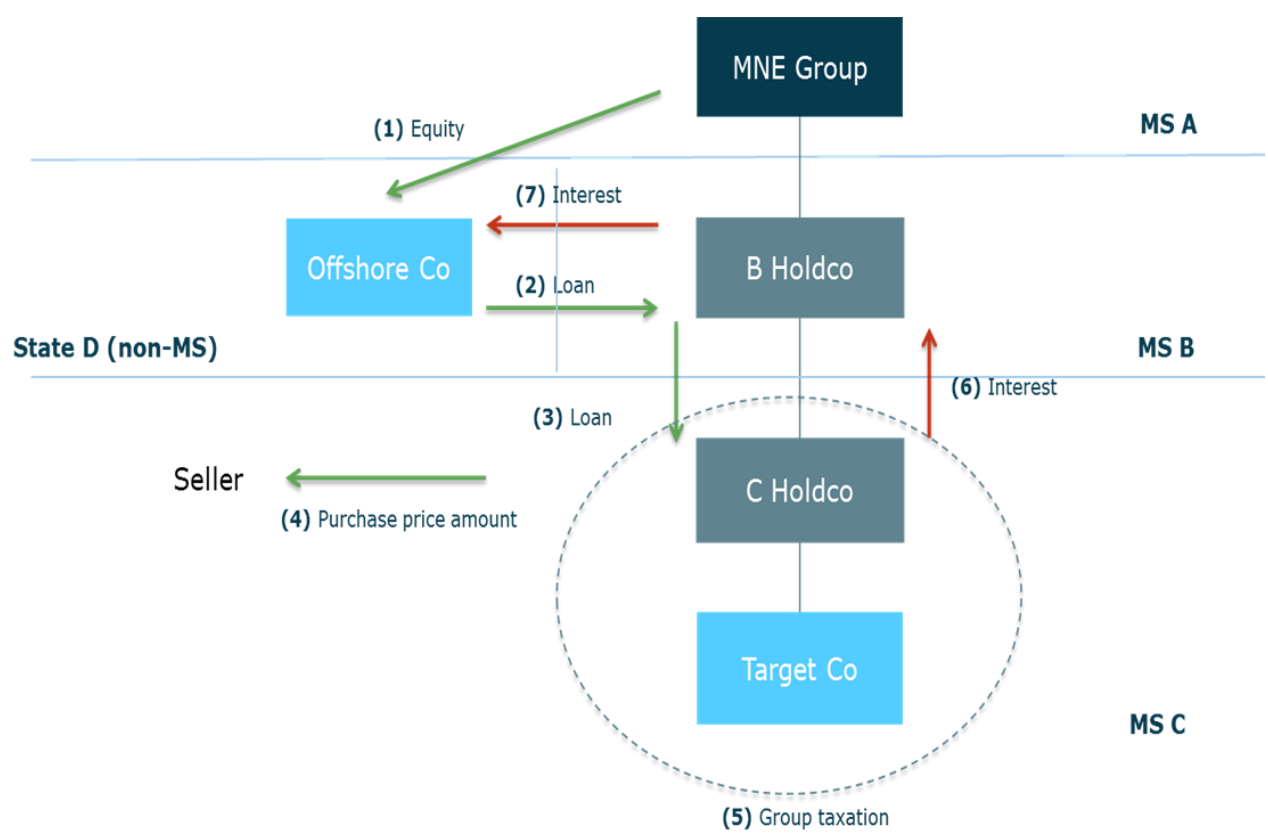

The current initiatives by the OECD and the EU seem to address the first element of a debt tax planning strategy which is to limit the ability to shift profits in both third party and intra group debt situations. ${ }^{15}$ In the

\footnotetext{
12 See also Offernanns, Huibregtse, Verdoner and Sood, BEPS Action 4: Policy Considerations and Implementation Status, European Taxation,2017, pp. 47-68.

${ }^{13}$ Other elements such as the lack of withholding taxes and CFC rules etc. are of course also important elements.

${ }^{14}$ See Study on Structures of Aggressive Tax Planning and Indicators, final report, Taxation Papers, Working Paper n. 612015 , ISSN 1725-7565, pp. 27-29.

${ }^{15}$ See also OECD BEPS action 4, chapter 4, para. 58. The $C(C) C B T$ touches the second element by harmonizing the tax base (not the tax rate).
} 
illustration above (model 1), this would be to enact interest limitation rules in MS C to protect the tax base in MS C and thereby ensure taxation where the economic activity takes place - not in State D. ${ }^{16}$

The issue is in which situations to deny the deductible, hence, when is the use of debt planning strategy acceptable tax planning and when is it unacceptable tax planning? How do we draw such a line? That has been addressed both by the OECD and the EU, and the main concern seems to be to identify whether or not the debt is used to finance economic activity that creates taxable income.

\section{OECD BEPS action 4}

In 2013, the OECD stated that the international tax principles to share tax jurisdiction may not have kept pace with the changing business environment, and a number of indicators showed more aggressive tax practices of some multinational companies which raised serious compliance and fairness issues. Such behavior was possible due to the lack of anti-tax avoidance rules and undermined competition, as some multinational companies obtained (unintended) competitive advantages through the access to sophisticated tax expertise. ${ }^{17}$ The OECD therefore concluded that - among other things - there was a need for interest limitation rules as addressed in action 4 of the OECD BEPS-project.

The final BEPS action 4 report was released October 5 2016, while an updated final version was released December $222016 .{ }^{18}$ The report contained recommendations on so-called best practices in the design of rules, in order to prevent base erosion through the use of excessive interest expenses and other financial payments. ${ }^{19}$ To design such an anti-tax avoidance rule, one must strike a balance between an effective and robust solution ct. a reasonably straightforward rule to apply for the taxpayer and tax authorities. ${ }^{20}$ Hence, it is about balancing simplicity and well-targeted rules. ${ }^{21}$ The aim is to ensure that deductible financing costs are directly linked to local economic activities by generating taxable income in the specific country (jurisdiction). ${ }^{22}$

The recommended best practice approach is based on a fixed ratio rule, where the net deduction of interest and payments economically equivalent to interest is limited to 10-30 pct. of the entity's or group's EBITDA (tax figures). The deductibility of net financing costs should therefore be maximized to 10-30 pct. of EBITDA.

The recommended approach to interest limitation rules represents a shift from denying deductibility of intragroup interest - due to the debt not being at arm's length (often assessed based on the ratio between debt and equity) - to deny the deductibility of all interest - due to the debt (interest) not having any direct connection to generating taxable income in the jurisdiction (EBITDA rules). ${ }^{23}$ It is basically a shift from the historically more widely used specific targeted interest limitation rules to a more general interest limitation rule. Such a

\footnotetext{
${ }^{16}$ CFC rules would protect the tax base of MS A.

17 See OECD BEPS action 4, introduction, pp. 23- 24.

18 The final OECD reports on the 15 Action Items against BEPS were released to the public on 5 October 2015.

${ }^{19}$ See also Millan and Roch, Limit Base Erosion via Interest Deduction and Others, Intertax 2015, pp. 58-71

${ }^{20}$ An EBITDA (earnings based) interest limitation is considered simpler than more classic debt focused thin capitalisation rules, see OECD BEPS action 4, chapter 4.

${ }^{21}$ See also Knöller, The Efficacy of Thin Capitalization Rules and Their Barriers: An Analysis from the UK and German Perspective, Intertax 2011, pp. 317-336

22 The BEPS Action Plan (2013) specifically required the development of rules to address base erosion and profit shifting using interest expense to fund tax exempt or tax deferred income. See more in OECD BEPS action 4 chapter 5.

${ }^{23}$ However, the OECD still acknowledges the simultaneous need for more targeted interest limitation rules incl. thin capitalization rules to address specific situations and risks.
} 
shift has already taken place in some European countries such as Germany, Denmark, Italy, Spain, Portugal, Norway, Finland and the post BEPS also in United Kingdom, and Iceland.

The recommended approached in OECD BEPS action 4 can be described as follows. ${ }^{24}$

The deduction of interest and payments economically equivalent to interest is limited to 10-30 pct. of the entity's/group's taxable EBITDA.The use of tax figures to calculate the EBITDA has the advantage of being "reasonably straightforward to apply and audit", it reduces the risk that an entity with negative EBITDA is required to pay taxes as a result of an interest disallowance, and makes it more difficult for a group to increase the limit on net interest deductions without also increasing the level of taxable income in a country. ${ }^{25}$ The corridor of 10-30 pct. from which a country individually can select the appropriate percentage, is an acknowledgement that not all countries are in the same position, which is also why EBIT may be used instead of EBITDA. ${ }^{26}$ But if a country choses to use an EBIT based limitation instead of EBITDA, the country can also apply a higher percentage, so the interest limitation rule is equivalent to 10$30 \%$. of the entity's/group's EBITDA in accordance with OECD BEPS action 4.

The limitation of the deductibility should include all deductible net financing costs. This includes intra group interest as well as third party interest, as not only intra group debt can be used in debt planning strategies as described above. A net calculation was chosen because a gross interest calculation may lead to double taxation and may be more vulnerable to tax planning according to the OECD. ${ }^{27}$ Further the limitation on the deductibility should also include payments economically equivalent to interest related to borrowing which is broadly defined and looks to economic substance rather that legal form. It is, therefore, a limitation on the deductibility of net financing costs.

The OECD does not define interest etc., but instead recommends that all these financing costs deductible according to national law should be within the scope of the interest limitation rule in order to avoid loopholes and to ensure fairness between taxpayers in the same situation by using different forms of finance arrangements. These finance arrangements and costs include:

- payments under profit participating loan

- imputed interest on instruments, such as convertible bonds and zero coupon bonds

- amounts under alternative financing arrangements, such as Islamic finance

- the finance cost element of finance lease payments

- capitalized interest included in the balance sheet value of a related asset, or the amortization of capitalized interest

- amounts measured by reference to a funding return under transfer pricing rules

- national interest amounts under derivative instruments or hedging arrangements related to an entity's borrowings

- certain foreign exchange gains and losses on borrowings and instruments connected with the raising of finance

- guarantee fees with respect to financing arrangements

\footnotetext{
${ }^{24}$ See also Offernanns, Huibregtse, Verdoner and Sood, BEPS Action 4: Policy Considerations and Implementation Status, European Taxation,2017, pp. 47-68.

${ }^{25}$ See OECD BEPS action 4, chapter 6, para. 88.

${ }^{26}$ See OECD BEPS action 4, chapter 6 for more on the fixed ratio corridor and Annex I.B

${ }^{27}$ See OECD BEPS action 4, chapter 4, para. 60 and 61. However it is also recommended that countries supplement the general interest limitation rules with targeted provisions which disallow gross interest expense in specific situations identified as posing base erosion and profit shifting risk.
} 
- arrangement fees and similar costs related to the borrowing of funds

If the net financing cost exceeds the fixed ratio (percentage of the entity's/group's EBITDA as selected in the country), the exceeding financing costs are not deductible as they are not considered to have a sufficient connection to the creation of taxable income (economic activity) in that country.

However, the OECD also acknowledges that interests and earnings may arise in different periods and therefore recommends that taxpayer is offered to:

- Carry forward disallowed financing costs,

- Carry forward unused capacity (unused EBITDA), and/or

- Carry back disallowed financing costs.

The above mentioned elements are the key elements in the recommended best practice on interest limitation rules from OECD in action 4, but alongside are some further adjustments to the simple assumption that net interest cost above the fixed ratio always constitutes profit shifting with no or little connection to the creation of taxable income in the country. These adjustments are described below.

As the purpose of the interest limitation rule is to focus on base erosion and profit shifting, the OECD acknowledges that certain entities with low net financing cost entail such a low risk that they should be excluded from the application of the interest limitation rule. The risk of BEPS is simply considered too low to justify the administrative costs in these situations. Countries can thus introduce a de minimis threshold based on the total net interest expense of all entities in the local group in order to exclude such low risk entities from the application of the interest limitation rule. The OECD does not set a specific threshold, but instead recommends that a country set the level of the de minimis threshold to reflect a number of factors, including the local economic and interest rate environment, as well as relevant tax or legal considerations.

Further, at the very least, the interest limitation rule should apply to entities in multinational groups, as the risk of base erosion and profit shifting is highest in multinational groups (main risk of BEPS). But a country can choose to only apply the rules to such multinational groups and not on domestic groups and standalone entities. Countries may apply the interest limitation rule to non-multinationals, including entities in a domestic group and/or standalone entities which are not part of a group for example to avoid competition issues between domestic and multinational groups, in order to reduce the general tax bias in favor of funding with debt over equity, or to comply with constitutional obligations or EU-law. ${ }^{28}$ Where a group has more than one entity in a country, the country may choose to apply the rule to each entity separately or to the overall group of entities in the same country (the local group), and thus, entities such as a SPV (holding company) can benefit from other group companies unused EBITDA capacity (operating company).

The OECD definitely considers multinational groups to be the main risk in relation to BEPS. However, the OECD also recognizes that some groups are "naturally" highly leveraged with third party debt, and therefore, recommends a so-called a group ratio rule alongside the fixed ratio rule. According to the OECD, a fixed ratio rule is a blunt tool which does not take into account the fact that some groups are more leveraged for non-tax reasons and the group ratio rule should not impose a stricter limit than the fixed ratio rule. The group ratio rule is calculated as the net third party interest and payments economically equivalent to interest percentage of the EBITDA of its worldwide group, and thereby, effectively replacing the 10-30

\footnotetext{
${ }^{28} \mathrm{~A}$ group can be defined due to being controlled or controls other entities or being part of a consolidated accounts. See OECD BEPS Action 4, part 1, chapter 3 for more.
} 
pct. of EBITDA (fixed ratio). This allows an entity to deduct net interest expenses in excess of the fixed ratio up to the group ratio. Countries may also apply an uplift of up to $10 \%$ to the group's net third party finance expenses to prevent double taxation and thereby increase the group ratio. ${ }^{29}$ The group information required to apply a group ratio rule should be taken from a group's consolidated financial statements, since consolidated financial statements provide the most reliable source of financial information on a worldwide group. ${ }^{30}$ The group ratio rule ensures that the interest limitation rule does not restrict the ability to obtain third party debt centrally in a country, where it is most efficient according to non-tax factors such as credit rating, currency and access to capital markets, and then lend on the borrowed funds within the group to where it is used to fund the group's economic activities.

The finalization of the OECD BEPS action plan was quickly picked up by the European Commission. The European Commission soon after launched the proposal for the Anti-Tax Avoidance Directive (January 28 2016) which includes an interest limitation rule based on OECD BEPS action 4.

\section{EU Anti-Tax Avoidance Directive (2016/1164) art. 4}

International tax law issues are also high on the agenda in the EU, and the EU as an institution was even represented in the BEPS project (as well as the Member States where independently represented). The focus in the EU is to ensure that tax is paid where the profits and value are generated in order to restore trust in the fairness of tax systems, and allow governments in their Member States to effectively exercise their tax sovereignty. ${ }^{31}$

Therefore, the European Commission welcomed the work of the OECD (BEPS project) and released a communication of 17 June 2015 to set out an action plan for fair and efficient corporate taxation in the European Union. ${ }^{32}$ Particularly, in response to the BEPS project, there was a push for a stronger and more coherent EU approach against corporate tax abuse. It was considered essential for the functioning of the internal market that Member States, at a minimum, fulfil their commitments under BEPS. ${ }^{33}$

On 28 January 2016, the European Commission presented the proposal for the Anti-Tax Avoidance Directive comprising of 6 anti-tax avoidance rules (interest limitation, exit taxation, switch-over-clause, general antiabuse rule, CFC, and hybrid rule). ${ }^{34}$ Only 5 month later, on 20 June 2016, the European Council adopted the directive $^{35}$ laying down 5 rules (interest limitation, exit taxation, general anti-abuse rule, CFC and hybrid rules) to counteract tax avoidance and aggressive tax planning which directly affected the functioning of the internal market.

The ATAD is a minimum directive setting the absolute minimum standard of anti-tax avoidance rules in the EU Member States and must, as a main rule, be adopted in the EU Member States as of 1 January 2019. This includes the interest limitation rule in art. 4. However, the implementation of the interest limitation rule can

\footnotetext{
${ }^{29}$ See OECD BEPS action 4, chapter 7, para. 117. A country can also choose to replace the group ratio rule with an "equity escape" rule as known in Germany and Finland, according to which an entity's level of equity and assets is compared to those held by its group.

30 See OECD BEPS Action 4, chapter 7, para. 122.

${ }^{31}$ See Anti-Tax Avoidance Package: Next steps toward delivering effective taxation and greater tax transparency in the EU, $\operatorname{COM}(2016) 23$ final.

32 See COM(2015) 302 final and Offernanns, Huibregtse, Verdoner and Sood, BEPS Action 4: Policy Considerations and Implementation Status, European Taxation,2017, pp. 47-68.

33 See $\operatorname{COM}(2015) 302$ final.

34 The Anti-Tax Avoidance Package consists of (i) the Anti-Tax Avoidance Directive, (ii) Recommendation on Tax Treaties, (iii)

Revised Administrative Coorperation Directive and (iv) Communication on External Strategy.

35 See also the proposal for Amending Council Directive 2016/1164 (COM(2016) 687 final).
} 
be postponed to 1 January 2024 or until the end of the first full fiscal year following the date of publication of the agreement between the OECD members on a minimum standard with regard to BEPS action 4, but only if the Member State as of 8 August 2016 already had national targeted rules for preventing BEPS risks, which are equally effective to the interest limitation rule set out in the ATAD and continue to apply these.

Member States are at a minimum to deny the deductibility of financing costs according to a fixed ratio, as described below. Member States can, in addition to the below described interest limitation rule, also apply more targeted rules against intra-group debt financing, in particular thin capitalization rules as also acknowledged by OECD.

Entities can only deduct exceeding ("net") borrowing cost up to 30 pct. of the taxable earnings before interest, tax, depreciation, and amortization (EBITDA) cf. art. 4 of the ATAD. The EU has thereby chosen to stay in the highest end of the OECD recommended fixed ratio corridor (10-30 pct.), but with the possibility of Member States to choose a lower fixed ratio. Further, it is possible for Member States to adopt an alternative measure referring to EBIT and fixed in a way that it is equivalent to the EBITDA-based ratio, as mentioned in the preamble and also acknowledged by OECD in BEPS action 4.

The definition of net borrowing costs is the amount of the deductible borrowing costs of a taxpayer according to national law that exceeds the taxable interest revenues and other economically equivalent taxable revenues which the taxpayer receives, i.e. a net calculation of financing cost. Borrowing cost are defined as interest expenses on all forms of debt, other costs economically equivalent to interest, and expenses incurred in connection with the raising of finance as defined in national law, including (as a minimum):

- payments under profit participating loan

- imputed interest on instruments such as convertible bonds and zero coupon bonds

- amounts under alternative financing arrangements, such as Islamic finance

- the finance cost element of finance lease payments

- capitalized interest included in the balance sheet value of a related asset, or the amortization of capitalized interest

- amounts measured by reference to a funding return under transfer pricing rules

- notional interest amounts under derivative instruments or hedging arrangements related to an entity's borrowings

- certain foreign exchange gains and losses on borrowings and instruments connected with the raising of finance

- guarantee fees with respect to financing arrangements

- arrangement fees and similar costs related to the borrowing of funds.

The mentioned costs economically equivalent to interest are identical with the wording in the OECD BEPS action 4 , while the interest revenues and other economically equivalent taxable revenues are not further defined.

If the net financing costs exceeds the fixed ratio, the entity cannot deduct these exceeding financing costs. However, a Member State can choose to allow a full deduction of exceeding borrowing cost up to 3 million EUR (de minimis) and only limit the deductibility of financing costs above the de minimis threshold. ${ }^{36}$ If an

${ }^{36}$ The OECD recommends a de minimis threshold to exclude the entities - not the financing costs - from the interest limitation rule. 
entity is limited by art. 4 of the ATAD, a Member State can - but are not obligated to - allow the entity to either:

1. Carry forward (no time limitation) the exceeding borrowing costs,

2. Carry forward (no time limitation) and carry back (up to 3 years) of exceeding borrowing costs, or

3. Carry forward (no time limitation) of exceeding borrowing costs and carry forward (5 years) of unused interest capacity (EBITDA).

This is in line with the OECD recommendation. Furthermore, there are certain exceptions and adjustments as described in the following to adjust the blunt assumption that net financing costs exceeding the fixed ratio is not connected to the creation of taxable income (economic activity).

Firstly, standalone entities can be exempted from the interest limitation rule, since they do not constitute a considerate risk of aggressive tax planning. A standalone entity means a taxpayer that is not part of a consolidated group for financial accounting purposes and has no associated enterprise or permanent establishment cf. art. 4, para. 3 of the ATAD.

Secondly, for groups - as defined in national tax law - the interest limitation rule can be applied on national group level, and thereby, enabling group entities such as holding companies to benefit from other group entities unused EBITDA capacity. The de minimis threshold is then apply at group level.

Thirdly, a Member State can in relation to entities part of a consolidated group for financial accounting purposes ${ }^{37}$ choose to give such entities the right to:

(i) a full deduction of the exceeding financing costs, if the entity can demonstrate that the ratio of its equity over its total assets is equal to or higher than the equivalent ratio of the group ( 2 pct. points deviation accepted) as calculated in consolidated financial statements using the same method, or

(ii) deduct exceeding financings costs up to the groups exceeding financings costs to third parties over the groups EBITDA thereby effectively obtaining a new higher fixed ratio for the entity (group ratio rule).

The second option (group ratio rule) is recommended by the OECD, while the first option is mentioned by the OECD as already used in some Member States incl. Germany and Finland.

In conclusion, the European Union has chosen to follow the recommendation in OECD BEPS action 4 quite closely and apply it as a minimum standard within the European Union. No matter the political commitment or intention of the Member State in the OECD BEPS project, EU Member States now have to comply with this interest limitation rule in the minimum directive as of 1 January 2024 at the latest and some even sooner if they do not have sufficient interest limitation rules in place. ${ }^{38}$ This will result in significant changes in many Member States, but might also set the standard in other countries, as described in the following.

\footnotetext{
37 See for definition art. 4, para. 8 in ATAD and art. 1, para. 2 in the Proposal for Amending Council Directive 2016/1164 (COM(2016) 687 final).

${ }^{38}$ Twenty-four Member States offered a general deductibility of interest costs without making it conditional on the creditor being taxed on the interest income and/or without imposing the full scale of thin-capitalization or other interest-limitation according to Study on Structures of Aggressive Tax Planning and Indicators, final report, Taxation Papers, Working Paper n. 61 2015, ISSN 17257565, p. 144.
} 


\section{Implications of the Best Practice and Minimum Standard of Interest Limitation Rule}

The best practice recommendation in OECD BEPS action 4 is - unlike the interest limitation rule in art. 4 of ATAD - only a recommendation and is not in itself binding for any country or jurisdiction. However, more than 100 countries and jurisdictions have committed to the OECD BEPS project and it is expected that countries and jurisdictions will look toward action 4, when introducing or amending exciting interest limitation rules, including non-BEPS project countries. The OECD BEPS action 4 is therefore highly relevant in many countries and jurisdictions whether or not the country actual being part of the OECD BEPS project. At the very least, all EU Member States must enact the similar interest limitation rule in art. 4 of the ATAD. BEPS action 4 and art. 4 of the ATAD are thus expected to have implications worldwide in some of the world's biggest economies and other countries, as analyzed below from a general perspective.

\subsection{Germany}

It is quite clear that the recommendations in OECD BEPS action 4 is inspired by the German interest limitation rule (Zinsschranke). ${ }^{39}$ The Zinsschranke replaced the German thin capitalizations rules in 2007 and Germany thereby went from a targeted interest limitation rule to a more general interest limitation rule.

The basic of the German interest limitation rule is that net financing costs are deductible up to 30 pct. of the entity's tax EBITDA. Entities which form a German tax group (Organschaft) are regarded as one entity (business) when applying the interest limitation rule. ${ }^{40}$ Non-deductible financing costs can be carried forward to subsequent years without time limitation, while excess capacity (EBITDA) can be carried forward up to 5 years. The German interest limitation rule seems to closely follow the OECD BEPS action 4 recommendations and the minimum requirements in art. 4 of ATAD - although more precisely, the OECD BEPS action 4 recommendations and the minimum requirements in art. 4 of ATAD seem to follow the German interest limitation rule.

Germany has enacted three escape clauses. ${ }^{41}$

Firstly, a de minimis rule clause applies, so the interest limitation rule only applies to entities with net financing costs exceeding 3 million EUR, and thereby, excluding entities with only a small amount of net financing cost (limited risk of BEPS).

Secondly, the interest limitation rule does not apply to stand alone entities, but only applies to group companies. A group is defined as entities being part of a consolidation with other entities (IFRS or other accounting standard) or as entities, where the financial or business decisions of the German entity may be uniformly controlled together with those of other entities. Such an escape clause is accepted by both the OECD and the EU, as the main risk of BEPS and aggressive tax planning seem to be with group companies, especially multinationals and not standalone entities.

Thirdly, the interest limitation rule does not apply to entities if the ratio of equity to total assets of the entity is equal or higher than the same ratio for the group, while a two percent-point deviation is accepted (IFRS or other accounting standard).

\footnotetext{
${ }^{39}$ See also Lambert, Meickmann and Reinert, Article 4 of the EU Anti-Tax Avoidance Directive in Light of the Questionable Constitutionality of the German "Interest Barrier" Rule, European Taxation, 2016, pp.323-327.

${ }^{40}$ See also Brocke and Perez, Group Financing: From Thin Capitalization to Interest Deduction Limitation Rules, International Transfer Pricing Journal, 2009, pp.29-35 and Millan and Roch, Limit Base Erosion via Interest Deduction and Others, Intertax 2015, pp. 58-71.

${ }^{41}$ See also Herzig, Lochmann and Liekenbrock, Impact Study of the New German Interest Capping Rule, Intertax, 2008, pp. 577-584.
} 
It should be noted that the two latter escape clauses (standalone and group escape clauses) do not apply if the entity has so-called harmful debt financing. Harmful debt financing consists of (i) interest to a shareholder with a direct or indirect shareholding of at least 25 pet. or a party related to such a shareholder or a third party lender with harmful recourse to the aforementioned and (ii) such interest amounts to at least 10 pct. of net financing costs. A more targeted rule is thus embedded in the interest limitation rule to apply this even stricter rule to those entities with harmful debt financing.

From an overall perspective, Germany is already compliant with action 4 and art. 4 of the ATAD, as the German interest limitation rule seem to have been the blueprint for action 4 and ATAD art. $4 .{ }^{42}$ Nevertheless, it is a bit unclear whether the German definition of financing expenses is wide enough as required in in the ATAD and recommended in action $4 .{ }^{43}$

In some situations, the German interest limitation rule seems stricter, since a more targeted rule has been embedded into the rule itself in regards to so-called harmful debt financing, which is compatible with action 4 and art. 4 of the ATAD. Other countries are definitely more affected by the new standard of interest limitation rules.

\subsection{Italy}

Italy was, alongside Germany, one of the first European countries to replace exiting classic thin capitalization rules with more general interest limitation rules. In 2008, a new interest limitation rule based on EBITDA was in effect and the focus in Italy was to have more general and simpler rules for the business community. ${ }^{44}$

In Italy, net financing costs in excess of 30 pct. of the entity's adjusted EBITDA cannot be deducted. EBITDA is, however, not calculated according to the tax statements, but instead according to the financial statements. Non-deductible net financing costs and excess EBITDA can be carried forward for subsequent years without any time limitation. ${ }^{45}$

Where an entity is part of a domestic tax consolidation regime, the interest limitation rule applies on a group basis, whereby an entity with excess EBITDA can be used be another group entity to reduce or eliminate a potential limitation of the deductibility of net financing costs. Furthermore, it should be noted that - under specific conditions - a non-resident subsidiaries can to ensure EU law compatibility also be included in the consolidation for the sole purpose of transferring their excess EBITDA-capacity in order to increase the overall interest deduction capacity of the Italian group. ${ }^{46}$

From an overall perspective, Italy has chosen a simpler solution than Germany and may be too lenient in some respect. If the adjusted EBITDA from the financial statement is higher than the tax EBITDA, the

\footnotetext{
42 See also Lambert, Meickmann and Reinert, Article 4 of the EU Anti-Tax Avoidance Directive in Light of the Questionable Constitutionality of the German "Interest Barrier" Rule, European Taxation, 2016, pp.323-327 and See also Gutmann, Perdelwitz, Raingeard, Offermanns, Schellekens, Gallo, Hap and Doorn-Olejnocka, The Impact of the ATAD on Domestic Systems: A Comparative Survey, European Taxation, 2017, pp. 2-20.

43 See also Marino and Russo, Italian Restyling of Interest Deduction Rules: the Amendments of the Italian Finance Bill for 2008, Intertax, 2008, pp. 204-210

${ }^{44}$ See also Marino and Russo, Italian Restyling of Interest Deduction Rules: the Amendments of the Italian Finance Bill for 2008, Intertax, 2008, pp. 204-210 and Millan and Roch, Limit Base Erosion via Interest Deduction and Others, Intertax 2015, pp. 58-71. ${ }^{45}$ See also Galeano and Rhode, Italy Sets the Barrier to Deduction of Financing Costs at 30 Per Cent of EBITDA, Intertax, 2008, pp.292-301.

${ }^{46}$ See also Marino and Russo, Italian Restyling of Interest Deduction Rules: the Amendments of the Italian Finance Bill for 2008, Intertax, 2008, pp. 204-210
} 
Italian interest limitation rule is not compliant with art. 4 of the ATAD and must be amended and may also be too lenient in regards to action 4. Further, it is unclear whether this transfer of excess EBITDA-capacity is in line with art. 4 of the ATAD as it will reduce the effect of the directive. ${ }^{47}$ On the other hand, this transfer (consolidation) might actually be required according to the freedom of establishment within the EU when such a consolidation is permitted in purely domestic situations. Some adjustments must therefore be expected.

\subsection{France}

France maintains a classic approach to interest limitation rules as they continue to apply thin capitalization rules, but with a modern or hybrid element build into the interest limitation rule.

The thin capitalization rules only apply to debt to related companies and third party debt guaranteed by related companies. The limitation only applies if (i) the debt to related companies over the equity exceeds the ratio of 1,5:1 and (ii) if the total amount if interest paid to related companies exceeds 25 per cent of the entity's pre-tax income (EBITDA-like element). Only (net) interest on related party debt etc. exceeding the threshold is non-deductible and may be carried forward to subsequent years (reduced 5 per cent annually from the second year). Two escape clauses exist, as interests are fully deductible if the entity shows that the entity's debt-to-equity ratio does not exceed the worldwide group's debt-to-equity ratio or if the nondeductible interest is less than 150,000 EUR (de minimis).

France is in need to amend its interest limitation rules in order to comply with action 4 and ATAD art. 4, especially in relation to the application of the interest limitation rule to both intra group and third party debt and not to apply a debt-to-equity ratio as de facto can function as a safe haven for entities. Significant changes must be expected in France. ${ }^{48}$

\subsection{United Kingdom}

As the United Kingdom is preparing to leave the European Union, a new interest limitation rule was enacted as of 1 April 2017 as part of the Finance Bill 2017. The new interest limitation rule replaced the so-called Worldwide Debt Cap. The new interest limitation rule is a clear response to action 4 and ATAD art. 4.

In the United Kingdom, net financing costs exceeding 30 pct. of the entity's tax EBITDA are non-deductible. The fixed ratio (30\% of EBITDA) may be replaced by the net financing costs to EBITDA for the worldwide group based on the consolidated accounts.$^{49}$ Non-deductible financing costs can be carried forward for subsequent years without time limitation, while unused EBITDA (interest allowance) can be carried forward up to 5 years. Furthermore, a de minimis threshold applies, so that groups with less than 2 million GPB of net interest expense are outside the scope of interest limitation rule.

The United Kingdom has now surely taken action 4 and ATAD art. 4 into its national law, and also continues to have more targeted rules on thin capitalization as part of the arm's length rules. Action 4 and art. 4 of the ATAD therefore already seem to have had a significant influence in the United Kingdom.

\footnotetext{
${ }^{47}$ See also Gutmann, Perdelwitz, Raingeard, Offermanns, Schellekens, Gallo, Hap and Doorn-Olejnocka, The Impact of the ATAD on Domestic Systems: A Comparative Survey, European Taxation, 2017, pp. 2-20.

${ }^{48}$ See also Gutmann, Perdelwitz, Raingeard, Offermanns, Schellekens, Gallo, Hap and Doorn-Olejnocka, The Impact of the ATAD on Domestic Systems: A Comparative Survey, European Taxation, 2017, pp. 2-20.

${ }^{49}$ See HMRC, Corporation Tax: tax deductibility of corporate interest expense, Policy Paper, Published 5 December 2016.
} 


\subsection{Scandinavia}

The Scandinavian countries have moved in different tempi in relation to interest limitation rules. As discussions where going on in Germany and Italy, similar discussions took place in Denmark, and thus, Denmark became the first country in Scandinavia to introduce a new interest limitation rule in effect from 1 July 2007, while others waited until 2014 and some are still discussing.

In Denmark, a new interest limitation rule based on EBIT were introduced in 2007 and formed part of the three interest limitation rules in Denmark. After applying a classic thin capitalization rule (1,5:1 ratio) and then an unique asset test interest limitation ( 3,2 pct. of the tax value of the entity's assets), the remaining deductible net financing cost will only be deductible up to 80 pct. of the entity's tax EBIT. Non-deductible net financing cost may be carried forward for subsequent years without time limitation. The interest limitation rule is applied on a consolidated basis for Danish group entities, where Danish entities can benefit from excess EBIT (interest capacity) in other group entities. A de minimis rule applies, so that only net financing costs in excess of 21,3 million DKK (approx. 3 million EUR) will be limited according to the rule. No other escape clauses exist, other than the de minimis threshold.

Other Scandinavian countries were also discussing interest limitation rules, but waited up until 2014 to introduce new interest limitation rules.

Finland enacted a new interest limitation rule from the tax year 2014. Historically, Finland did not have interest limitation rules, as a working group in 1995 concluded that Finland did not need such rules. ${ }^{50}$ However, in a newer study from 2009, the Ministry of Finance concluded that the general debt to equity ratio of Finnish-held companies was greater than that of foreign-owned companies, and that the ratio of equity to debt borrowed from associated entities was higher than in domestically owned companies. Finland, therefore, chose to enact an interest limitation rule and looked towards the German EBITDA based interest limitation rule. ${ }^{51}$

The Finnish interest limitation rule limits the deductibility of net financing costs to 25 pct. of the tax EBITDA. Net financing costs exceeding 25 pct. of the EBITDA cannot be deducted. Nevertheless, the actual limitation only applies to net financing costs on related party debt, including back-to-back loans, as the limitation is caped at the financing costs on related party debt (transfer pricing definition). ${ }^{52}$ Even though financing costs on third party debt is included in the calculation and application of the interest limitation rule, the interest limitation rule does not limit the deductibility of financing costs on third party debt. This is clearly a deviation from the German rule, as well as action 4 and ATAD art. 4. Non-deductible financing costs can be carried forward for subsequent years without time limitation. Two escape clauses exist:

- a de minimis of 500,000 EUR applies so that entities with net financing cost (related and third party interest) up to 500,000 EUR are exempted from the interest limitation rule.

- the interest limitation rule does not apply if the entity demonstrates that the ratio of equity and total balance of the entity (financial statement) is greater than or equal to the group' s consolidated balance sheet.

\footnotetext{
50 See Penttilä and Nieminen, Interest Deduction Limitation Rules Introduced, European Taxation, 2013, pp. 237-242.

51 When the new Finnish rules were drafted, a thin capitalization regime was not among the legislative alternatives that were seriously considered. See Penttilä and Nieminen, Interest Deduction Limitation Rules Introduced, European Taxation, 2013, pp. 237242.

52 See Penttilä and Nieminen, Interest Deduction Limitation Rules Introduced, European Taxation, 2013, pp. 237-242.
} 
Simultaneously with Finland Norway also introduced a new interest limitation rule in 2014. In Norway, net financing costs exceeding 25 pct. of the entity's EBITDA cannot be deducted (30 pct. before 2016). The interest limitation rule is applied separately to entities without any consolidation. Non-deductible financing cost can be carried forward for up to 10 years. Like the Finnish rule, the actual non-deductibility only applies to net financing costs on related party debt and a de minimis rule of 5 million NOK applies, so entities with net financing cost (related and third party interest) up to 5 million NOK are exempted from the interest limitation rule. If the net financing costs exceed 5 million NOK, the interest limitation rule applies fully as in Finland, but unlike Denmark. No other escape clauses presently exist.

Norway is currently considering the following amendments to the interest limitation rule as of $2018::^{53}$

- Expand the rule to also limit the deductibility of third party financings costs, but only for multinationals (not pure domestic entities or groups)

- To increase the de minimis threshold to 10 million NOK

- Introduce an escape clause based on debt/equity ratio of the entity or the Norwegian domestic group compared to the whole group (financial statement)

Most recently, Iceland (as of 1 January 2017) introduced an interest limitation rule. In Iceland, an entity cannot deduct net financing cost exceeding 30 pct. of the entity's tax EBITA assessed on a standalone basis. As in Finland and Norway, the actual limitation only applies to related party net financing costs. There is no carryforward or carryback of disallowed net financing costs. The interest limitation rule does not apply to entities with net financing cost less than 100 million ISK or to net financing costs paid to related party resident in Iceland. Also, an equity escape clause exist so entities that demonstrates that the equity ratio is no more than two percentage-points below the consolidated groups equity ratio is outside the scope of the interest limitation rule. ${ }^{54}$

Lastly, Sweden, which in contrast to the other Scandinavian countries, does not have general interest limitation rules such as an EBITDA based interest limitation rule, but only have more targeted interest limitation rules. In Sweden, interest paid to a related entity is not deductible, unless the interest would have been taxed at a minimum of 10 pct. at the hands of the beneficial owner (but irrelevant if main reason is to obtain a substantial tax benefit), or if related to an acquisition, where the acquisition of the participation right and the underlying loan are primarily motivated by business reasons and the actual recipient is resident in an EEA country, or a country which has a tax treaty with Sweden. There have been serious discussions of amending the Swedish interest limitation rules and in June 2017 a new report was released by the Swedish Finansdepartementet. ${ }^{55}$ The report suggest to a new interest limitation rule based on earnings is to be effect as of 1 July 2018 in combination with a reduction of the corporate income tax rate from 22 pct. to 20 pct. The report suggests to limit the deductibility of net financing costs to either 35 pct. of EBIT or 25 pct. of EBITDA. The interest limitation rule is to apply to both intra group and third party debt. A modest de miminis rule of 100.000 SEK is also suggested and thereby bringing such low net financing costs outside the scope of the interest limitation rule. A carryforward of 6 years is suggested by Finansdepartementet.

In conclusion all the Scandinavian countries seem to have to make some adjustments to their current interest limitation rules to comply with action 4 and art. 4 of the ATAD. For example, it is unclear whether Denmark can continue to apply 80 pct. of the tax EBIT as the ratio, as 30 per cent of the EBITDA or an equivalent

\footnotetext{
${ }^{53}$ See Høringsnotat - Forslag til endringer i rentebegrensningsreglerne, Saksnr. 17/1850, dated 4 Maj 2017.

${ }^{54}$ See Sigurvaldadottir, The Newly Implemented Interest Deduction Limitation Rule, European Taxation, 2017, pp. 108-112.

55 See Finansdepartementet, Nya skatteregler för företagssektorn, June 2017, Fi2017/02752/S1.
} 
percentage of EBIT is the maximum according to the ATAD. But then again, it must be remembered that two interest limitation rules are applied before the EBIT-rule, whereas a situation in which Denmark allows a deduction in excess of the ATAD may rarely or never arise.

Finland, Norway, and Iceland only apply their interest limitation rule to intra-group debt (financing costs), while the interest limitation rules are to be applied to all debt, according to action 4 and art. 4 of the ATAD (Norway and Iceland are not EU Member States). However, action 4 and art. 4 of the ATAD both allow an escape clause where the fixed ratio (30 per cent of EBITDA) is replaced by the ratio between financings costs to third parties over the groups' EBITDA. This will in effect limit the scope of the interest limitation rule, but as the recommended/minimum new fixed ratio is connected to the groups' financing costs and EBITDA it is not the same as to never apply interest limitation rules to third party debt. Norway is considering expanding the scope to third party debt, but only for multinationals, which would be compatible with the action 4. Further Iceland does not apply their interest limitation rule to pure domestic debt which does not seem compliant with the fundamental freedoms in the EEA agreement, ${ }^{56}$ and does not allow a carryforward or carryback, as recommended in action 4.

At last, Sweden presently has a unique approach to interest limitation rules in a Scandinavian context. Their current approach does not follow the best practice recommendation in action 4 and is very different from the minimum standard in art. 4 of the ATAD. The Swedish rule is too lenient when granting deductibility to net financing cost exceeding 30 per cent of EBITDA in relation to both third party debt and intra group debt. Some significant changes must therefore be expected in the Swedish interest limitation rules ${ }^{57}$, due to art. 4 of the ATAD, as also recently analyzed and discussed by the Swedish Finansdepartementet.

\subsection{North America}

North America (meaning the United States and Canada) has historically taken different paths to interest limitation rules. This is still the case, and none of them have (yet) implemented the best practice recommendations in action 4 .

In the United States, the (old) ${ }^{58}$ earning stripping rule has been in place since 1989. The earning stripping rule is a form of hybrid between a classic thin capitalization rule and an EBITDA (income) based interest limitation rule. The rule applies if the entity is thin capitalized, meaning that the debt-to-equity ratio exceed 1,5:1. Further, the rule only applies if the net financing costs exceed 50 pct. of the adjusted taxable income ("EBITDA"). If so, the net financing costs exceeding the fixed ratio (50 pct.) is non-deductible. However, the non-deductibility only applies to related party debt, and only if such interest are not subject to full US withholding tax. Non-deductible financing cost can be carried forward indefinitely, while excess "EBITBA" can be carried forward for 3 years.

Canada continues to have classic thin capitalization rule according to which an entity cannot deduct interest on related debt to non-residents, if the entity's debt-to-equity ratio exceeds 1,5:1 as an average calculation of the monthly high. If the entity is thinly capitalized, the excess financing costs are non-deductible. The excess (non-deductible) financing cost is calculated as the total financing costs multiplied with the excess debt divided by the total debt. Not only are the financing cost non-deductible, but they are also recharacterized to dividends, and thus, a withholding tax may apply.

\footnotetext{
${ }^{56}$ See also Sigurvaldadottir, The Newly Implemented Interest Deduction Limitation Rule, European Taxation, 2017, pp. 108-112.

${ }^{57}$ See also on the recent interest limitation cases Ostas and Hilling, America Business Law Journal, 2016, pp. 745-785.

${ }^{58}$ A new earning stripping rule addressing 6 specific transactions were proposed on 4 April 2016 to run alongside the old earning stripping rule.
} 
As briefly described above, none of the countries have yet complied with action 4 and continue to apply different interest limitation rule; Canada applies a classic thin capitalization approach, while the United States applies a hybrid interest limitation rule. It is very uncertain whether the recommended best practice approach - the clearly German inspired approach - will be implemented in North America.

\subsection{Asia}

In Asia - here only focusing on China and Japan - the classic thin capitalization rules are still the preferred interest limitation rule.

In China, excess intra-group interest cannot be deducted if the debt-to-equity ratio exceeds 2:1 and the excess interest will be re-characterized to dividends, unless the entity can document that the interest is at arm's length. There is neither access to carryforward nor carryback of non-deductible interest, as these are considered dividends and therefore are non-deductible.

Japan has also enacted thin capitalization rules, according to which, the interest on intra-group debt to a nonresident controlling shareholder cannot be deducted if the debt-to-equity ratio exceeds $3: 1$. The debt-toequity ratio of 3:1 can, however, be replaced by the debt-to-equity ratio of a comparable resident entity, if available.

Both China and Japan are therefore still only targeting intra-group debt (non-arm's length) and use the classic debt-to-equity approach to determine whether or not the interest (debt) can be considered to be at arm's length. The wider recommend approach in action 4 has yet to be implemented in both countries.

\subsection{Summery}

The European Commission was worried that a divergent implementation of the OECD BEPS Final Reports, including action 4, would create distortions, clashes, tax obstacles, and fragment the so-called single market in the EU Member States. ${ }^{59}$ The European Commission therefore felt a need for a (minimum) unilateral implantation.

As shown above, it is clear that some European countries had already taken steps into the direction of what has now become best practice according to action 4, and a minimum standard according to ATAD art. 4. However, most EU Member States must make adjustments and widen the scope of the interest limitation rule to comply with action 4/ATAD art. 4, or even introduce new interest limitation rules if no or only thin capitalization rules have been implemented. ${ }^{60}$ Only a few European countries seem to be ahead of action 4 and ATAD art. 4 or being in the process of implementing such rules, while Non-European countries still have time to implement such a best practice approach, if wanting to.

The pressure of the ATAD has - of course - forced EU Member States to begin the process of implementing interest limitation rules at least as strict as ATAD art. 4, and thereby, at a minimum implement some measures from action 4 . Nevertheless, it could also indicate that action 4 was primarily driven by European countries, such as Germany, and that it will take time for the OECD recommended best practice to broaden outside the European boundaries. It is therefore uncertain whether these non-EU Member States, including

\footnotetext{
59 See $\operatorname{COM}(2015) 302$ final.

${ }^{60}$ See also Study on Structures of Aggressive Tax Planning and Indicators, final report, Taxation Papers, Working Paper n. 61 2015, ISSN 1725-7565.
} 
the above-mentioned and developing countries, will implement action 4 if they consider themselves to be the unintended "victims" of aggressive tax planning etc. or will look at alternative measures.

\section{Alternatives Measures}

The problem of debt tax planning strategies seems to be relatively easy to understand, but difficult to solve in an effective and well-targeted way. ${ }^{61}$ Hence, the question arises whether an EBITDA-based interest limitation rule is the best solution, for example in situations where an investment fails, or a market changes and no profit is generated, and thus no deduction is given according to an EBITDA-based interest limitation rule. ${ }^{62}$ The answer - of course - depends on what is considered to be the problem and the alternatives to such an interest limitation rule.

If it is acknowledged that the problem is two-folded as (i) the ability to shift profit through deductions and (ii) the incentive to do so through the different tax values (tax value of deduction and taxation of lender), other alternatives than the EBITDA-based interest limitation rule may be considered; such as the following where focus is on either taxation of the lender, or the deductibility at the hands of the borrower.

A full global harmonization of tax rates and tax base would obviously eliminate most tax driven base erosion and profit shifting, while a territorial consolidation in each country could still give rise to some tax planning. A global harmonization of tax rates would similarly reduce the use of some of these debt tax planning strategies, as the incentives to do so would be reduced. Although, such a global harmonization of tax rates or tax base seem impossible. ${ }^{63}$ The most recent and ambitious attempt seems to be the European Commission's push for a common (consolidated) corporate tax base ${ }^{64}$ within the European Union. As the directive's proposals only relate to the European Union and the proposals do not seem to be enacted in the near future within the EU, the harmonization of tax rates or tax base do not seem to be a viable solution on a short or medium term future - maybe not even in the long term. Instead, one could look towards more unilateral approaches.

A country could introduce withholding taxes on the receiving lender to level out the difference between the tax value of the deduction and the taxation of the creditor. This would effectively eliminate some debt tax planning strategies, where the debt is simply used to shift profit from one country to another, due to the different tax values (rates). However, such an approach would not eliminate the incentive in some cases, if non-deductible dividends would be taxed in the hands of the investor and could further result in double taxation, depending on tax credits etc. Furthermore, such an approach would completely change the way countries presently divide taxing powers, according to the OECD and UN Model Tax Convention. In both tax treaty models, ${ }^{65}$ only interest ${ }^{66}$ can be taxed in the source state (not financial income in a broad sense), and in the OECD MTC only up to 10 pct. of the gross amount of the interest, while the threshold is not determined in the UN MTC. Also, within the EU, no withholding tax can be applied to interest payments between associated entities, according to the Interest and Royalty Directive (2003/49/EC). A withholding tax

\footnotetext{
61 See also Knöller, The Efficacy of Thin Capitalization Rules and Their Barriers: An Analysis from the UK and German Perspective, Intertax 2011, pp. 317-336.

62 See also Martins, Corporate Financing, Interest Deduction and Tax Controversies, Intertax 2013, pp. $462-469$.

${ }^{63}$ See also de Groot, Interest Deduction and the CCCTB: A Walk in the Park for Tax Advisors, Intertax 2013, pp. 571-580. "Tax competition, whether harmful or harmless, will exist as long as the global maze of different tax systems exists. The only way to ban harmful tax competition is to introduce a global tax system: something that remains in the realm of the impossible."

64

65 See art. 11 in both models.

66 As defined in art. 11, Para 3 in both models.
} 
on all financial income would therefore be a significant change in the international tax system to a more source-based taxation and could give rise to increased double taxation.

Instead, a suggestion could be to look at the borrower and the correlation with the lender. Remembering that one of the key elements in a debt tax planning strategy is the difference between the tax value of the deduction at the hands of the borrower, and the taxation of the lender another approach could be to have a variable value of the deduction which would then correspond to the actual taxation of the lender. Such a measure would result in a complete neutral tax treatment of the financial payments ${ }^{67}$ which means that a nontaxation of the lender would result in a non-deduction, while a 10 percent taxation would result in an equal tax value of the deduction. ${ }^{68}$ This would be a new, dynamic, and highly variable general deduction rule which would entail a high administrative burden on the taxpayer (borrower) and the tax authorities, if applied in all cases, and fully variable to completely match the taxation of the lender. As shown above, Sweden currently has a very rough version (full or no deduction), where a 10 percent taxation or less of the lender would result in non-deductibility at the hands of the borrower, and even in this rather simplistic approach, it creates uncertainty and administrative burdens ${ }^{69}$ But from a theoretical perspective it would be an option and it should also be noted that according to the ECJ, such a limitation of the deductibility, corresponding to the taxation of the lender, does not constitute a withholding tax and would therefore not infringe the Interest and Royalty Directive (2003/49/EC).$^{70}$ However, it would be a very bold and uncommon approach that would significantly change the principles of taxation, as the taxation of one taxpayer (borrower) would depend on the taxation on another taxpayer (lender).

Instead, it is definitely more common to have specific targeted interest limitation rules, which would be an alternative to the above-mentioned EBITDA-based solution. This includes classic thin capitalization rules and asset based interest limitation rules which are still in effect in many countries, especially outside Europe. Both were also discussed in the OECD BEPS project action $4 .{ }^{71}$

The purpose of classic thin capitalization rules is to deny the deductibility of interest if the debt is not at arms' length, and therefore, constitutes an objectified form of case-by-case arms' length regulation. ${ }^{72}$ Historically, most countries have used a fixed ratio of debt-to-equity ${ }^{73}$ to assess whether or not intra-group debt is at arms' length - i.e. the more debt the entity has obtained; the more likely it is that the intra-group debt could not have been obtained between unrelated parties. As also addressed in OECD BEPS action 4, thin capitalization rules are more targeted than an EBITDA-based interest limitation rules, and thus, the latter would usually have a much wider scope than thin capitalization rules. The OECD points to a number of disadvantages, such as the classic thin capitalization rules allowing a significant flexibility in terms of the interest rate (the more debt; the higher rate) and it is relatively easy to manipulate the outcome of the test by

\footnotetext{
${ }^{67}$ However, neutrality in the debt vs. equity (interest vs. dividends) is still not achieved.

68 See also de Groot, Interest Deduction and the CCCTB: A Walk in the Park for Tax Advisors, Intertax 2013, pp. 571-580. "The major advantage of such an interest deduction limitation compared to, for example, an EBIT/EBITDA or equity/debt test is that it is not procyclical: a fall in profits does not lead to a corresponding rise in the amount of deductible interest subject to limitation. This way the issue at the heart of the matter, namely taking advantage of different tax rates to save tax, is addressed..."

${ }^{69}$ See also on legal uncertainty with reference to Adam Smith Ostas and Hilling, America Business Law Journal, 2016, pp. 745-785.

${ }^{70}$ See Scheuten Solar Technology GmbH C-397/09. It is however not clear whether it could be considered a withholding in other situations outside the scope of the Interest and Royalty Directive, see for example Athinaïki Zithopiïa C-294/99, including the opinion of the Advokat General.

71 See annex III.B of OECD BEPS action 4.

72 See also Knöller, The Efficacy of Thin Capitalization Rules and Their Barriers: An Analysis from the UK and German Perspective, Intertax 2011, pp. 317-336.

73 The ratio differs from country to country as well as if all debt or only intra group debt is compared to the entity's equity.
} 
adjusting equity, and thereby, obtain higher deductions which result in base erosion and profit shifting. ${ }^{74}$ The OECD, therefore, concludes that such debt-to-equity based test should not be included as a general interest limitation rule, but that such tules can play a role as targeted rules to specific risks in relation to excess debt. $^{75}$

It seems fair to conclude that classic thin capitalization rules cannot capture all debt planning strategies, as it is not the purpose of classic thin capitalization rules. Classic thin capitalization rules must be considered as targeted rules, and thus, only suitable for capturing non-arm's length debt; whether applied based on a fixed debt-to-equity ratio or case-by-case assessment of the intra-group debt. ${ }^{76}$ Hence, thin capitalization rules cannot be seen as a perfect alternative to the recommended best practice in action 4 , but can be used as supplement to a general interest limitation rule, if the general interest limitation rule does not sufficiently capture the specific risk of intra-group debt as also concluded by the OECD. ${ }^{77}$

The OECD also discussed the possibility of using assets as a measurement for economic activity, as an alternative to earnings in the interest limitation rule. ${ }^{78}$ Some authors consider assets as the best measurement for the activity of a business. ${ }^{79}$ Such an approach is applied in Denmark as a primary rule, where net financing costs exceeding $3.2 \%$ (2017) of the tax value of the entity's assets (excluding shares etc.) cannot be deducted. ${ }^{80}$ An EBIT-based rule also applies as a supplement (secondary rule) to the remaining deductible financial costs, as described above.

According to the OECD, the main benefit of an asset-based approach is that asset values typically are more stable, and therefore, should give rise to a relatively steady and predictable interest limitation. This would improve certainty and reduce compliance costs. ${ }^{81}$ Moreover, the interest limitation rule would not affect entities only because of incurring losses from their economic activities. However, at least three concerns arise. Firstly, such an interest limitation rule must take all assets which drive the value creation into account and exclude assets which give rise to non-taxable income, as also mentioned by the OECD. Secondly, these assets must be valued in a consistent and acceptable manner. The OECD acknowledges that it would be an excessive compliance burden and impractical to use market values, and that an amortized historic cost valuation could give rise to inconsistencies and unlikely represent the actual value of the contribution to the economic activity. Also, the OECD finds that the accounting standards often impose stringent requirements before intangible assets are recognized. Since intangible can often be the most valuable type of assets in a modern global business, the use of an accounting valuation (method) would exclude one of the cornerstones of the economic activity and value driver in the business! Thirdly - but not mentioned by the OECD - it seems very unclear how to connect the maximum interest to the assets (determine the percentage used) which also seems to be the case with connecting interest to the fixed EBITDA ratio. The OECD is not impressed by such an alternative. The OECD stipulates that in a situation, where the economy of a country is highly reliant on heavily capitalized groups whose activities rely on tangible fixed assets with long depreciation periods, earnings should still be a suitable measure of economic activity for the purposes of

\footnotetext{
${ }^{74}$ See OECD BEPS action 4, Introduction, Para. 17.

75 See also OECD BEPS, Actoin 4, chapter 9, Para. 169.

76 This has also been described as the choice between a rule-based approach with a clear ex-ante meaning and a standard approach with an ex post assessment, see Knöller, The Efficacy of Thin Capitalization Rules and Their Barriers: An Analysis from the UK and German Perspective, Intertax 2011, pp. 317-336.

77 See also OECD BEPS action 4, chapter 9 on the impact of thin capitalization rules.

78 See OECD BEPS action 4, chapter 5, pp. 48-50.

79 See also Martins, Corporate Financing, Interest Deduction and Tax Controversies, Intertax 2013, pp. 462-469.

80 See Sec. 11 B of the CTA.

81 See OECD BEPS action 4, chapter 5, para. 79.
} 
applying. But in such a case, asset values may exceptionally be used as an acceptable alternative. ${ }^{82}$ From a theoretical perspective, assets seem to provide a better measurement of economic activities, but do in practice give rise to a lot of issues, including identification and valuation of the assets, as well as (un)certainty. An asset based model is therefore not a better solution for the seemingly impossible task of trying to identify what the money (debt/interest) has been used for each year; whether or not it is generating tax exempt income or not.

In summary, there does not seem to be a perfect solution for anti-tax avoidance measures in relation to debt planning strategies, as long as countries and jurisdictions have different corporate income tax rates, and the main rule still is that financing expenses are per se deductible. ${ }^{83}$ Even in situations where interest etc. are deductible as a business expenses (ordinary/necessary/indispensable etc.) and it is either assumed or somehow documented that the financing expenses is incurred to generate taxable income, there still seems to be a need for interest limitation rules as such anti-tax avoidance rules are in place in many countries. This illustrates and supports how difficult it is to establish a connection between a loan (and the costs hereof) and the actual use of the (generic) money i.e. which part of the entity's activities are financed by equity and which part by loans. In this authors opinion, it is impossible (or nearly impossible) which is why these interest limitation rule will always be a second best solution, as long as the different treatment of equity and debt (dividends and interest etc.) exits and financing cost can be used to shift profits to low tax countries.

This is a self-created problem caused by inconsistencies in (international) tax law and, as long as these inconsistencies exist, it seems to be a matter of patching up a leaking boat and trying to strike the best balance between establishing the closest connection to the taxable income (economic activities), administrative burdens and (un)certainty. An asset-based interest limitation rule seems most appropriate to establish the maximum of debt which have been used (or could have been used) to finance the relevant economic activities, but only if these activities (or assets) can be identified and valued in a reliable way, while an EBITDA based interest limitation rule seems most appropriate in relation to minimizing the administrative burdens of both the taxpayer and the tax authorities. Although, the low administrative cost come at a prize; no actual assessment of a connection to the economic activities is made - it is just assumed that financing cost exceeding $30 \mathrm{pct}$. of the EBITDA is not connected to the economic activities, which generates taxable income ${ }^{84}$ It is a political choice of balancing the pros and cons, but this author would prefer that countries looked more into the fundamentals of the tax system instead of adding further (insufficient) anti-tax avoidance measure to the already complex (international) corporate tax system, as it comes at a prize. ${ }^{85}$

\section{Conclusion}

It is clear that aggressive tax planning and base erosion and profit shifting constitute a problem in our global world. It is, however, not clear what is meant by aggressive tax planning/BEPS and therefore where and how to draw the line between acceptable and unacceptable debt tax planning.

\footnotetext{
82 See OECD BEPS action 4, chapter 5, para 83.

${ }^{83}$ See also Martins, Corporate Financing, Interest Deduction and Tax Controversies, Intertax 2013, pp. 462-469.

${ }^{84}$ The OECD has done a study on the net financing cost/EBITDA-ratio, which is the basis for the 10-30 pct. ratio recommended by the OECD. See OECD BEPS action 4, annex I.B.

${ }^{85}$ See also Ostas and Hilling, America Business Law Journal, 2016, pp. 745-785. They argue for a more pragmatic approach to law, rather than a formalistic one, because the traditional formalistic approach to law facilitates aggressive planning rather than hinders it (legal pragmatism as a realistic alternative to positive legal formalism).
} 
The OECD has presented their best practice solution in action 4 recommending a fixed ratio interest limitation rule based on 10-30 percent of the tax EBITDA, including some escape clauses. Action 4 is also the basis for ATAD art. 4. ATAD art. 4 enacts the minimum requirements to interest limitation rules in the EU Member States and require all Member States to at least have an interest limitation rule, which maximizes the deductible net financing costs to 30 percent of the tax EBITDA and also include some escape clauses. It is quite clear that the German interest limitation rule seems to be the blueprint for action 4 , and thereby, also for ATAD art. 4.

Most countries are not as prepared as Germany to comply with action 4 and/or ATAD art. 4, as shown above. Most European countries do not presently comply with the ATAD and must therefore make smaller or larger changes to their existing interest limitation rules or introduce new interest limitation rules. Most Non-European countries do not yet seem to have fully embraced action 4 and it will thus be interesting to see whether these countries will support action 4 by implementing the best practice interest limitation rule into their national tax law.

As shown above, as long as tax rates and tax bases are not internationally harmonized, debt tax planning strategies can and will be used to shift profits away to low(er) tax countries by the use of deductible finance costs. Currently, EBITDA-based interest limitation rules seem to be the best solution, but this simple blunt tool comes at a prize; it is not well-targeted and EBITDA is a variable difficult to predict which results in uncertainty in the ongoing business decisions. Maybe it is time to truly consider the inconsistencies in (international) tax law instead of trying to patch up the corporate tax law with more and more anti-tax avoidance rules. 